\title{
In Vitro Antiplasmodial Activity, Cytotoxicity, Antioxidant Action and GC-FID Analysis of Allanblackia Floribunda Extracts
}

Francis Irabor ( $\nabla$ francis.irabor@yahoo.com )

Michael and Cecilia Ibru University https://orcid.org/0000-0003-2982-8066

Osamudiamen Ebohon

Michael and Cecilia Ibru University

Nekpen Erhunse

International Centre for Genetic Engineering and Biotechnology, New Delhi, India

Osariemen Tinu Okugbo

Benson Idahosa University

Ehimwenma Sheena Omoregie

University of Benin

Research

Keywords: Antiplasmodial activity, cytotoxicity, Plasmodium falciparum, Allanblackia floribunda, IC 50

Posted Date: June 9th, 2020

DOl: https://doi.org/10.21203/rs.3.rs-32060/v1

License: (c) (i) This work is licensed under a Creative Commons Attribution 4.0 International License. Read Full License

Version of Record: A version of this preprint was published at SN Applied Sciences on September 28th, 2021. See the published version at https://doi.org/10.1007/s42452-021-04812-0. 


\section{Abstract}

Background: Malaria is a disease that is caused by Plasmodium parasite that has resulted in death of so many persons in the world especially children below 5 years. Plasmodium falciparum is one of the most widespread etiological agent for human malaria and has become increasingly resistant to standard antimalarial drugs. This study was therefore aimed at evaluating the in vitro antiplasmodial efficacy and cytotoxicity of Allanbackia floribunda stem bark, leaf and oil.

Methods: Trager and Jensen method was used to culture Plasmodium falciparum and maintained in fresh $\mathrm{O}$ + human erythrocytes at $3 \%$ hematocrit in complete medium (Roswell Park Memorial InstituteRPMI 1640). Mark III test developed by WHO was used to assess the antiplasmodial activity of the plant's crude extract and fractions against the ring stage of P. falciparum strains Pf3D7. Cytotoxicity was determined against Vero cell line using microculture tetrazolium (MTT). GC-FID was employed to identify bioactive constituents in the most active fraction.

Results: The plant extracts showed varied degrees of inhibition of parasitaemia with IC 50Pf3D7 values ranging between 4.0 to $1000 \mu \mathrm{g} / \mathrm{mL}$. The methanol stem bark extract of A. floribunda exhibited very active antiplasmodial activity (IC 50Pf3D7 $=4.3 \pm 0.17 \mu \mathrm{g} / \mathrm{mL}$ ), the leaf extract showed active antiplasmodial activity (IC 50Pf3D7 $=8.0 \pm 0.28 \mu \mathrm{g} / \mathrm{mL}$ ) while the oil extract was inactive against the parasite (IC $50>100 \mu \mathrm{g} / \mathrm{mL}$ ). Both the leaf and stem bark extracts were found to be non-cytotoxic in contrast to the standard cytotoxic drug, doxorubicin. The selectivity indices (S.I.) of the extracts against the parasites were 13.32 and 8.18 for the stem bark and leaf, respectively. Among the stem bark fractions, dichloromethane (DCM) had the best inhibition against the P. falciparum parasite (DCM IC 50Pf3D7 of $1.51 \mu \mathrm{g} / \mathrm{mL}$ ) and was closely followed by the hydromethanol (HMet) fraction (HMet IC 50Pf3D7 of 5.0 $\mu \mathrm{g} / \mathrm{mL}$ ) while that of ethylacetate (EAct) and hexane (Hxn) fractions were almost similar (IC 50 Pf3D7 of 6 and $6.25 \mu \mathrm{g} / \mathrm{mL}$, respectively).GC-FID analysis of the most active fraction, DCM, showed high presence antiplasmodial flavonoids (naringenin, luteolin, kaemferor and myricetin) and terpenes (a-pinene and $\beta$ caryophyllene) which may have been responsible for the excellent antiplasmodial action of the most active fraction.

Conclusion: This investigation confirmed that $\mathrm{A}$. floribunda stem bark has potent activity against $\mathrm{P}$. falciparum and it is relatively safe to normal cell. The antiplasmodial action is credited to the presence of bioactive flavonoids and terpenes that may have acted singly or synergistically.

\section{Background}

Malaria is a disease that is caused by Plasmodium parasite. The symptoms and clinical manifestations of this protozoan infection is severe in children, pregnant women and individuals from malaria free regions when compared to subjects who have been pre-exposed to the infection. Artemisinin-base combination therapy (ACT) recommended by $\mathrm{WHO}$ for the treatment of uncomplicated malaria has been effective in combating this malady. However, the scourge of the disease is still fierce in sub-Saharan 
Africa because of the mortality rate on a yearly basis. [1]. For example, there are approximately $216,000,000$ cases of malaria infection worldwide resulting in 445,000 death with $91 \%$ of the mortality in Africa [1]. It has been impossible to eliminate malaria from under-developing regions such as Africa due to the existence of hard-to- reach communities, inaccessibility of antimalarial drugs, exposure to fake antimalarial drugs, drug resistance, lack of information flow about effective antiplasmodial agents and individuals' low income status. Despite the death toll resulting from parasite plaque in Nigeria, some indigenous people are able to control the ravaging effect to some extent by using plant-based products. Medicinal plants are known to be rich in bioactive substances with varied pharmacological properties on living systems [2]. However, some plant constituents may cause toxicity to man. Toxicity is the relative ability of a substance to cause adverse effects in living organisms [3]. The concept of toxicity as opined by Paracelsus is with respect to dose, i.e. the amount of substance determines whether it effects will be toxic, nontoxic or beneficial. Information on the therapeutic efficacy and health safety of medicinal plants has been based on oral communication through successive generations among indigenous people for many years. However, the scientific validation of their therapeutic properties still remain unproven.. Recent reports in eastern [4], northern and southern [5, 6] regions of Nigeria suggest possible cases of parasite resistance and recrudescence to the currently used combined antimalarial therapies. Hence, the necessity to investigate and find possible replacement for the first line combination therapies commonly used in Nigeria. In order to contribute to the scientific data of $A$. floribunda and develop effective antimalarial drug, its antiplasmodial and cytotoxic activities were investigated.

\section{Methods}

\section{Collection of Plant Stem bark, Leaf and Fruit}

The plant parts used in this study were selected based on ethnopharmacological

information as antimalarial plant used in southern part of Nigeria. Allanblackia floribunda leaf, stem bark and seed were collected during the period of January and July, 2016, from a forest area at Ohogua community, Ovia East Local Government, Benin City, Edo Sate, Nigeria. The plant was authenticated by a Botanist at the Department of Plant Biology and Biotechnology, Faculty of Life Sciences, University of Benin, Nigeria and voucher specimen of the sample $\left(\mathrm{UBHA}_{361}\right)$ was deposited the herbarium of the same department.

\section{Preparation Of Extract}

$100 \mathrm{~g}$ of the macerated $A$. floribunda stem bark and leaf were soaked in $1000 \mathrm{~mL}$ of absolute methanol for $72 \mathrm{~h}$ with occasional stirring. The extracts were then filtered using double layered muslin cloth and the filtrate concentrated to dryness by using a rotary evaporator at reduced pressure while the oil was obtained from about $200 \mathrm{~g}$ of the powdered seed using hot water floatation method. The extracts obtained were stored at $4 \llbracket \mathrm{C}$ until used. 
Fractionation of the stem bark extract was done using solvent of increasing polarity as described by Hassan et al. (2012). The methanol stem bark extract of $A$. floribunda was partitioned into fractions of nhexane, dichloromethane, ethyl acetate and hydromethanol. The fractions obtained were concentrated using a rotary evaporator (RE 300, Bibby Scientific, UK) with reduced pressure at $45^{\circ} \mathrm{C}$ and final concentrate was obtained using silica gel.

Qualitative Phytochemical Screening and antioxidant activity of A. floribunda stem bark Fractions

The qualitative test for phytochemicals present in fractions were carried out using standard procedures $[7,8]$. The free radical scavenging capacity of the fractions against 1,1-diphenyl-2-picrylhydrazyl (DPPH) radical was determined by a modified method of Brand-Williams et al. [9]. Phosphomolybdate reduction capacity was estimated using the method described by Prieto et al. [10].

\section{Cultivation Of Parasites}

Trager and Jensen procedure was used to culture $P$. falciparum [11, 12]. The Plasmodium strain (Pf3D7) used was chloroquine sensitive isolated from Nigeria and India, respectively. The parasites were cultured in $0+$ RBC as host cells and maintain in RPMI 1640 medium supplemented with gentamicin solution $0.01 \mathrm{mg} / \mathrm{mL}, 25 \mathrm{mM} \mathrm{HEPES}$ buffer, $25 \mathrm{mM} \mathrm{NaHCO}_{3}$ and $1 \%$ Albumax II maintained in $5 \% \mathrm{CO}_{2}$ and incubated at $37^{\circ} \mathrm{C}$. Parasitaemia was determined using light microscopy (Giemsa stain).

\section{In Vitro Antiplasmodial Activity}

The growth inhibition of chloroquine-sensitive Plasmodium falciparum strain (3D7) by the plant extracts was evaluated by means of the Mark III test, as developed by the WHO [13]. Filter sterilized extracts (25, $12.5,6.25,3.12,1.56,0.78$ and $0.39 \mu \mathrm{g} / \mathrm{mL}$ ) were incorporated in 96-well plate containing $200 \mu \mathrm{L}$ of $0.5 \%$ P. falciparum culture that had been synchronized and diluted to $3 \%$ hematocrit with red blood cells. Wells with parasitized red blood cells without plant extract serve as negative controls whereas wells containing cultures with chloroquine diphosphate serve as positive control. Parasitaemia was evaluated after $48 \mathrm{~h}$ by Giemsa stain and the average suppression of parasitaemia was calculated.

\begin{tabular}{|c|c|}
\hline $\begin{array}{l}\text { Average \% suppression } \\
=\end{array}$ & $\begin{array}{l}\text { Average \% parasitaemia in control } ₫ \text { Average \% parasitaemia in } \\
\text { test }\end{array}$ \\
\hline & $x 100$ \\
\hline of Parasitaemia & Average $\%$ parasitaemia in control \\
\hline
\end{tabular}

The antiplasmodial activities of the extracts were expressed using IC $\mathrm{C}_{50}$. The IC $\mathrm{C}_{50}$ is the inhibitory concentrations of the drug/extracts that induced $50 \%$ reduction in parasitaemia compared to control 
(100\% parasitaemia). It was determined using SPSS statistical tool pack based on interpolation from the parasite growth inhibition curve generated from each plant extract. Each sample was tested in duplicate and the $\mathrm{IC}_{50}$ obtained were pooled and expressed as geometric means and standard deviations. The independent sample t-test was used to compare mean $\mathrm{IC}_{50}$ of antimalarial activity between plant extracts using STATA version 13 (Software Stata Corp, College Station, TX, USA). Finally, the in vitro antiplasmodial activity was rated in accordance with the system of antiplasmodial activity of Rasoanaivo et al. [14].

\section{Cytotoxicity Test (cell Viability Assay)}

Monkey kidney epithelial cell (LLC MK2) were used to assess the cytotoxicity of the most active plant extract. Vero cells were maintained in Dulbecco's Modifed Eagle's medium (DMEM) supplemented with $10 \%$ fetal bovine serum FBS, glutamine $(2 \mathrm{mM})$, penicillin (100 units / $\mathrm{mL}$ ) and streptomycin $(100 \mu \mathrm{g} /$ $\mathrm{mL}$ ). The cells were seeded in 96 well plates at 10,000 cells per well in $100 \mu \mathrm{L}$ culture medium. The cells

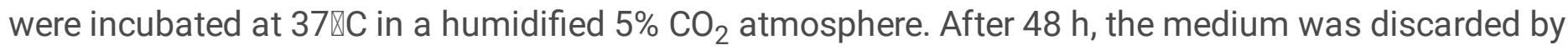
inversion of the microtitre plate and thereafter replaced with $100 \mu \mathrm{L}$ of fresh culture medium followed by $100 \mu \mathrm{L}$ of crude plant extract at a concentration of $1000 \mu \mathrm{g} / \mathrm{mL}$ in row $\mathrm{H}$ of the 96 well plate and serially diluted twofold to give concentrations ranging from 500 to $7.81 \mu \mathrm{g} / \mathrm{mL}$. Row A. of the 96 well plate serve as control wells, whereby the negative control contained culture medium and the LLC-MK2 cells without plant extract (Maximal cell growth). The cells were maintained at 37 in a $\mathrm{CO}_{2}$ incubator before determining their viability by using MTT assay as described by Mosmann [15]. The absorbance for each well was measured between $490-630 \mathrm{~nm}$ in a micro-titre plate reader and the percentage cell viability (CV) was calculated using the formula:

$\mathrm{CV}=$ Average Absorbance of dublicate drug wells $\times 100$

Average absorbance of control well

A dose-response curve was plotted to calculate the concentration that destroyed $50 \%$ of the Vero cells $\left(\mathrm{CC}_{50}\right)$.

\section{Gas Chromatography (gc) Analysis Of Most Active Fraction (n-hexane)}

The flavonoids, terpenes, alkaloids, terpenoids, quinones and volatile organic constituents profile of the nhexane fraction was determined using gas chromatography with flame ionization detector. Gas chromatography analysis was carried out on a HP 6890 Powered with HP ChemStation Rev. A 09 01[1206] Software.

\section{Statistical Analysis}


The statistical analyses of the results were carried out. The various results obtained from this study were expressed as mean \pm SEM. One way analysis of variance (ANOVA) followed by Tukey's HSD (honest significant difference) test was used to determine significance differences between the groups. Statistical significance was declared when $P$ value was less than 0.05 . The statistical analysis was performed using the statistical package for social science (SPSS) for windows, version 16.0 .

\section{Results}

\section{In vitro antiplasmodial activity of A. floribunda stem, leaf and oil extract}

The inhibition of parasite growth by the plant extracts was dose dependent from 0.05 to $25 \mu \mathrm{g} / \mathrm{mL}$ except for $A$ floribunda stem bark extract which had a higher percentage inhibition (30\%) at $0.025 \mu \mathrm{g} /$ $\mathrm{mL}$ compared to $26 \%$ at $0.05 \mu \mathrm{g} / \mathrm{mL}$. At 5 and $25 \mu \mathrm{g} / \mathrm{mL}$ both leaf and stem bark extracts had over $50 \%$ parasite inhibition. However, $A$. floribunda oil extract recorded less than $41 \%$ of $P$. falciparum inhibition even at the highest dose (Fig. 1). The $\mathrm{IC}_{50}$ values of the tested medicinal plant against $P$. falciparum are listed in Table 1. The stem extract of $A$. floribunda showed excellent antiplasmodial activity $(4.3 \pm 0.17 \mu \mathrm{g} / \mathrm{mL})$ followed by the leaf extract $(8 \pm 0.28 \mu \mathrm{g} / \mathrm{mL})$. However, the oil extract showed $\mathrm{IC}_{50}$ value that was over $100 \mu \mathrm{g} / \mathrm{mL}$.

\section{Cytotoxic activity of A. floribunda crude stem and leaf extract}

Results of the cytotoxicity evaluation against Vero cell line of $A$. floribunda stem bark and leaf extracts are shown in Fig. 2. At 7.8 to $125 \mu \mathrm{g} / \mathrm{mL}$ of the two plant extracts the cell viability was majorly close to $50 \%$ and above. However, at $500 \mu \mathrm{g} / \mathrm{mL}$ the percentage cell viability was below $20 \%$. The methanol extracts of $A$. floribunda exhibited no significant activity against the Vero cell line with $\mathrm{CC}_{50}$ values of $57.53 \mu \mathrm{g} / \mathrm{mL}$ (stem bark) and $65.5 \pm 2.5 \mu \mathrm{g} / \mathrm{mL}$ (leaf). The standard cytotoxic drug, doxorubicin was found to be highly cytotoxic having $\mathrm{CC}_{50}$ of $0.62 \pm 0.05 \mu \mathrm{g} / \mathrm{mL}$; the selectivity index for $A$. florinbunda leaf was lower (8.18) when compared with the stem bark extract (13.32), Table 2.

Phytochemical composition, in vitro antiplasmodial and antioxidant activity of the partitioned fractions of A. floribunda methanol stem bark extract

Table 3 depicts the phytochemical screening results of the partition fractions of $A$. floribunda stem bark extract,. The result revealed the presence of quinones, flavonoids, cardiac glycosides, alkaloids, terpenoids, tannins and phenols in all the fractions studied. Majority of the phytochemicals were highly detected in the dichloromethane, ethylacetate and hydromethanol fractions. However, some of these bioactive substances were less detected in the hexane fraction. Quinones were undetected in the hydromethanol fraction. Figure 3 represents the result of the total antioxidant capacity which parallels that of the phytochemical screening of the different stem bark fractions of $A$. floribunda. The reduction of molybdenum ( $\mathrm{VI})$ to molybdenum $(\mathrm{V})$ by the fractions was highest in the hydromethanol $(205 \mu \mathrm{g} / \mathrm{mL})$ 
followed by ethylacetate fraction $(101.4 \mu \mathrm{g} / \mathrm{mL})$ and then the dichloromethane $(93.2 \mu \mathrm{g} / \mathrm{mL})$. The hexane fraction had the lowest antioxidant activity $(82.4 \mu \mathrm{g} / \mathrm{mL})$. DPPH radical scavenging activity of the stem bark fractions of $A$. floribunda (Fig. 4) was over $70 \%$ at a concentration range of 20 to $100 \mu \mathrm{g} /$ $\mathrm{mL}$. An exception to this is the activity recorded for hexane fraction in which less than $60 \% \mathrm{DPPH}$ radicals were inhibited at $100 \mu \mathrm{g} / \mathrm{mL}$. Table 4 shows the $\mathrm{IC}_{50 \mathrm{DPPH}}$ of the various fractions as follow: ethylacetate $\left(\mathrm{IC}_{50 \mathrm{DPPH}}=5 \times 10^{-4} \pm 0.0001 \mu \mathrm{g} / \mathrm{mL}\right)$, hydromethanol $\left(\mathrm{IC}_{50 \mathrm{DPPH}}=8 \times 10^{-4} \pm 0.0005 \mu \mathrm{g} / \mathrm{mL}\right)$ and dichloromethane $\left(\mathrm{IC}_{50 \mathrm{DPPH}}=2.89 \pm 0.33\right)$. Ethylacetate, hydromethanol and dichloromethane fractions were as good as the standard antioxidant compound, vitamin $\mathrm{C}\left(\mathrm{IC}_{50} \mathrm{DPPH}=4 \times 10^{-4} \pm 0.00 \mu \mathrm{g} / \mathrm{mL}\right)$. However, the antioxidant capacity of the hexane fraction ( $\mathrm{IC}_{50}=192 \pm 14.1 \mu \mathrm{g} / \mathrm{mL}$ ) was low and significantly different from others at $p<0.05$.

The activity of the various fractions of $A$. floribunda stem bark with respect to inhibition of parasite growth is shown in Table 4 and Fig. 5. Among the fractions, dichloromethane (DCM) had the best inhibition against the $P$. falciparum parasite $\left(D C M=I C_{50 P f D 3} 1.51 \mu \mathrm{g} / \mathrm{mL}\right)$ and was closely followed by the hydromethanol (HMet) fraction (HMet $\left.=\mathrm{IC}_{50} P f D 35.0 \mu \mathrm{g} / \mathrm{mL}\right)$ while that of ethylacetate (EAct) and hexane $(\mathrm{Hxn})$ fractions were almost similar $\left(\mathrm{IC}_{50} \mathrm{PfD}_{3}=6\right.$ and $6.25 \mu \mathrm{g} / \mathrm{mL}$, respectively). In general, the in vitro antiplasmodial activity of the fractions followed the order: $\mathrm{DCM}>\mathrm{HMet}>\mathrm{EAct}>\mathrm{Hxn}$.

\section{Gas chromatography flame ionization detector (GC-FID) analysis on dichloromethane fraction (most active fraction)}

According to table 5, flavonoid profile of dichloromethane fraction showed the presence of higher level of kaemferol; other flavonoids found in high amount are catechin, naringenin, luteolin, epigallocatechin, quercetin and myricetin (Fig. 6). In Table 6, azulene, a-pinene, pinene-2- ol, y-terpinene, camphor, 1, 8cineole, borneol, neryl acetate, $\beta$-Caryophyllene and humulene were the terpenes found in relatively high amount (Fig. 7). Humulene was significantly higher in the terpenes profile compared to others. Chrysophanol (Fig. 8) was the only significant quinone detected in high proportion while others like aloe emodin, rhein and emodin were found in low levels respectively, table 7. In table 8, terpenoids profile showed the presence of low a-amyr in, and $\beta$-amyrin in the DCM fraction but their concentrations were still much higher than others like taraxerol, lupeol, bauerenol acetate (Fig. 9). alkaloids and volatile organic constituents profiles were generally low in phytochemicals, however, alkaloids such as coniine, coniceine, cassine, spectaline and volatile organic constituents like butanoic acid, 2-methyl butenoic acid were detected in relatively higher amount compared to others which were extremely low, table 9 and table 10 (Figs. 10 and 11)

\section{Discussion}

Allanblackia floribunda stem bark, leaf and oil extracts were examined for their in vitro antiplasmodial ability and cytotoxic activity; Fractionation of the most active crude extract was done and phytochemical screening, in vitro antioxidant and antiplasmodial assays were further investigated, finally, analysis of the 
most active fraction was carried out with GC-FID. The result of this investigation showed that the inhibition of parasite growth by the plant extracts in vitro was dose dependent. At 5 and $25 \mu \mathrm{g} / \mathrm{mL}$ both leaf and stem bark had over $50 \%$ parasite inhibition. However, $A$. floribunda oil extract recorded less than $41 \%$ of $P$. falciparum inhibition even at the highest dose. The in vitro antiplasmodial activity was analyzed in accordance with the system of antiplasmodial activity of Rasoanaivo et al.[9]. According to this norm, an extract is regarded to be very active if $\mathrm{IC}_{50}<5 \mu \mathrm{g} / \mathrm{mL}$, active if $5<\mathrm{IC} C_{50}<50 \mu \mathrm{g} / \mathrm{mL}$, weakly active $50 \mu \mathrm{g} / \mathrm{mL}<\mathrm{IC}_{50}<100 \mu \mathrm{g} / \mathrm{mL}$ and inactive $\mathrm{IC}_{50}>100 \mu \mathrm{g} / \mathrm{ML}$. IC $\mathrm{IC}_{50}$ is the inhibitory concentrations of the drug/extracts that can cause $50 \%$ reduction in parasitaemia level. The stem extract of $A$. floribunda showed excellent antiplasmodial activity followed by the leaf extract. However, the oil extract showed $I_{50 P\{3 D 7}$ value that was over $100 \mu \mathrm{g} / \mathrm{mL}$, hence inactive against the parasite in vitro. Partition fractionation of the crude stem bark extract of $A$. floribunda and in vitro antiplasmodial activity showed that the DCM fraction was highly active against the parasite with $I_{50 P f 3 D 7}$ of $1.5 \mathrm{mg} / \mathrm{ml}$ compared to the other fractions. Ayoola et al. [16] and other authors had earlier reported the traditional use of $A$. floribunda for the treatment of malaria $[17,18]$. Azebaze et al. [19] recorded similar $I C_{50}$ with isolate of Allanblackia gabonensis, and Allanblackia monticola against Plasmodium parasite. GC-FID analysis of $A$. floribunda DCMI fractions showed the presence of flavonoids (Kaempferol, catechin, naringenin, luteolin, epigallocatechin, quercetin and myricetin) and terpenes (a-pinene, pinene-2- ol, $\mathrm{Y}^{-}$ terpinene, camphor, 1,8-cineole, borneol, neryl acetate, $\beta$-Caryophyllene, and humulene) some of which have been reported to be potent against $P$. falciparum $[20,21,22]$.

Herbert and fellow researchers suggested possible mechanisms of how terpenes inhibit Plasmodium parasite growth. Jomaa et al. [23] reported that isoprenoid biosynthesis in Plasmodium falciparum depends on the DOXP/2-C-methyl-d-erythritol-4-phosphate (MEP) pathway while in humans, isoprenoids are synthesized via the mevalonate pathway [24]. This made isoprenoid biosynthesis a potential target for $P$. falciparum especially in the presence of phytochemicals such as terpenes. Some malaria researchers [25] opined that terpenes inhibit dolichol biosynthesis in the trophozoite and schizont stages and that this bioactve compound (terpenes) may be acting through inhibition of the isoprenyl diphosphate synthases. This family of enzymes catalyzes consecutive 1'-4 condensations of isopentenylPP with the allylic substrate to form the linear backbone for all isoprenoid compounds, including prenylated proteins, prenylated quinones, and dolichol [26]. Due to the structural similarity terpenes have with the substrates required for dolichol synthesis, it might interfere with the parasite's biosynthesis of polyisoprenoids by competing with original substrates in enzyme-substrate reactions or by interfering with the mechanisms of elongation of isoprenic chains [25]. This metabolic interference may cause parasite death as seen in the crude extract of $A$. floribunda methanol extracts because of the presence of secondary metabolites like terpene (16). Other possible mechanisms of parasite inhibition by the plant extracts could be through prevention of merozoites invasion of erythrocytes, inhibition of haemozoin biocrystallization by the alkaloids, inhibition of $P$. falciparum fatty acid biosynthesis and protein synthesis disruption by triterpenoids $[27,28,29,30]$. 
The result of the cytotoxicity study showed that the stem and leaf extracts of $A$. floribunda were non-toxic as against the standard cytotoxic drug, doxorubicin (an anthracycline antibiotic) which was found to be highly cytotoxic". According to the American National Cancer Institute $(\mathrm{NCl})$, the threshold for crude extract toxicity is $\mathrm{CC}_{50}$ less than $30 \mu \mathrm{g} / \mathrm{mL}$ [31]. However, a crude plant extract with $\mathrm{CC}_{50}$ less than $20 \mu \mathrm{g} / \mathrm{mL}$ is considered highly cytotoxic [32]. In the light of $\mathrm{NCl}$ guidelines, $A$. floribunda extracts at 7.81 to about $125 \mu \mathrm{g} / \mathrm{mL}$ were considered to be non-cytotoxic because their respective $\mathrm{CC}_{50}$ were significantly greater than $30 \mu \mathrm{g} / \mathrm{mL}$. The selectivity indices, a ratio of $\mathrm{CC}_{50}$ to $\mathrm{IC}_{50 P f 3 D 7}$ revealed that the extracts were selectively toxic to the parasite and safe to mammalian cells with the stem bark having a higher selectivity for Plasmodium falciparum when compared to leaf. However, worked done by some other researchers [34, 35, 36, and 37] on the hearthwood and the root bark of Allanblackia floribunda reported that the xanthones, benzophenones, and some biflavonoids of $A$. floribunda exhibited cytotoxic activity. This may be possible due to the fact that the amount of secondary metabolites present in A. florinbunda may be higher in the root and hearthwood compared to their concentrations in the stem bark and leaf. Besides, the time of plant harvest and geographical location may also influence the levels of plant's bioactive compounds. These two factors may account for the difference in the cytotoxicity result. In this study, the constituents of $A$. floribunda probably had little or no effect on Vero cell line, hence $A$.

floribunda maybe considered safe to normal cells but toxic to malaria parasite. This finding somewhat, to certain extent, validates the claim of traditional healers about the safety of $A$. floribunda decoction when administered orally to individuals having fever associated with malaria.

\section{Conclusion}

Findings from this study show that $A$. floribunda methanol stem bark and leaf extracts have some levels of activity against Plasmodium falciparum parasite and are relatively non-toxic to normal cells. The antiplasmodial action is credited to the presence of bioactive flavonoids and terpenes that may have acted singly or synergistically. This therefore supports the use of $A$. floribunda in the treatment of malaria in ethno-medicinal practices. However, the plant extract should be subjected to more investigations to identify the active compounds in its methanol extracts and elucidate their antiplasmodial mechanisms.

\section{Declarations}

\section{Ethical Approval}

The study was approved by the Institutional Ethics Review Committee, University of Benin (LS19114).

\section{Consent for Publication}

Not applicable.

\section{Availability of data and materials}

All data generated and analysed are included in this research article and its supplementary information fles. 


\section{Competing interests}

The authors declare that they have no competing interests.

\section{Funding}

This work received financial support from Obariase Foundation. Equally, the in vitro testing was materially supported by Dr. Olumide Adebesin, Department of Cell Biology and Genetics, University of Lagos.

\section{Authors' contributions}

ESO, FI, OE and NE design the study. FI, OE, OTO and NE carried out experimental work. FI and NE analysed the data. FI wrote the manauscript. All authors read and approved the final manuscript.

\section{Acknowledgements}

The authors will like to acknowledge Department of Biochemistry, university of Benin; Department of Basic Sciences, Benson Idahosa University; Department of Cell Biology, University of Lagos, Department of Biochemistry, National Institute of Medical Research and Metro Research and Biotechnology Africa Limited for their technical supports and research facilities

\section{Authors Details}

1Department of Biological and Chemical Sciences, Faculty of Natural and Applied Sciences, Michael and Cecilia Ibru University Agbarha-Otor, P.M.B 100, Ughelli, Delta State, Nigeria. 2International Centre for Genetic Engineering and Biotechnology, New Delhi, India. 3Department of Basic Sciences, Faculty of Basic and Applied Sciences, Benson Idahosa University, Benin City, Nigeria. 4Department of Biochemistry, Faculty of Life Sciences, University of Benin P.M.B 1154, Benin City, Nigeria.

\section{References}

1. WHO

Geneva: World Health Organization

WHO. World malaria report 2018. Geneva: World Health Organization; 2018. https://apps.who.int/iris/bitstream/handle/10665/275867/97892 41565653-eng.pdf?ua = 1 .

2. Butler MS. The role of natural product chemistry in drug discovery. Journal of Natural Product. 2004;67:2141-53.

3. Ariens E, Simonis AM, Offermeir J. Introduction to General Toxicology. Academic Press 1976; New York NY.

4. Ajayi NA, Ukwaya KN. Possible ACT resistant malaria in Nigeria - A report of 3 cases. Rev Soc Bras Med Trop. 2013;46(4):525-7.

5. Wundermann GS, Osiki AA. Currently observed trend in the resistance of malaria to artemisinin based combination therapy in Nigeria - a report of 5 cases. Int j trop dis health. 2017;21(2):1-5. 
6. Ebohon O, Irabor F, Ebohon LO, Omoregie ES. Therapeutic failure after regimen with artemetherlumefantrine combination therapy: a report of three cases in Benin City, Nigeria. Rev Soc Bras Med Trop. 2019;52:e20190163.

7. Trease GE, Evans WC. Pharmacognosy. 11th edition London Bailliere Tindall Ltd. 1989; Pp. 60-75.

8. Harborne JB. Phytochemical Methods, London, Chapman and Hall, Ltd. 1973; Pp. 49-188.

9. Brand-Williams W, Cuvelier ME, Berset C. Use of a free radical method to evaluate antioxidant activity. LWT-Food Sci Technol. 1979;28:25-30.

10. Prieto $P$, Pineda $M$, Anguilar M. Spectrophotometric quantitation of antioxidant capacity through the formation of a phosphomolybdenum complex: Specific application to the determination of Vit $\mathrm{E}$. Analytical Biochem. 1999;269:337-41.

11. Trager W, Jensen JB. Human malaria in continuous culture. Science. 1976;193:673-5.

12. Olasehinde GI, Olusola O, Adegboyeg OA, Obasola EF, Neena V, Isaac OA, Adesola AA, Louis OE. In vitro studies on the sensitivity pattern of Plasmodium falciparum to anti-malarial drugs and local herbal extracts. Malaria Journal. 2014;13:63.

13. WHO. In vitro micro-test (Mark III) for the assessment of P. falciparum to, mefloquine, quinine, amodiaquine, sulfadoxine/pyrimethamineand artemisinin. Geneva, Switzerland: CTD/MAL/9720 Rev 2; 2001.

14. Rasoanaivo A, Ravi P, Petitjean S, Ratsimamanga-Urverg A, Rakoto R. Medicinal plants used to treat malaria in Madagascar. J Ethnopharmacol. 1992;37:117-27.

15. Mosmann T. Rapid colorimeter assay for cellular growth and survival: Application to proliferation and cytotoxicity assays. J Immunol Methods. 1983;65(1-2):55-63.

16. Ayoola GA, Coker HA, Adesegun SA, Adepoju-Bello AA, Obaweya K, Ezennia EC. Phytochemical screening and antioxidant activities of some selected medicinal Plants used for malaria therapy in Southwestern Nigeria. Trop J Pharm Res. 2008;7:1019-24.

17. Burkill HM. The useful plants of West Tropical Africa. Royal Botanical Garden Kew. 1985;4:385-6.

18. Odugbemi TO. Outlines and Pictures of Medicinal Plants from Nigeria. Lagos: University of Lagos Press; 2006. p. 137.

19. Azebaze AGB, Teinkela JEM, Nguemfo EL, Valentin A, Dongmo AB, Vardamides JC. Antiplasmodial activity of some phenolic compounds from Cameroonians Allanblackia. Afri Health Sci. 2015;15(3):835-40.

20. Salehi B, Upadhyay S, Erdogan OI, Kumar Jugran ALD. Jayaweera SA, Dias D, et al. Therapeutic Potential of $\alpha-$ and $\beta$-Pinene. A Miracle Gift of Nature. Biomol. 2019;9(11):738. https://doi.org/10.3390/biom9110738.

21. Soré $H$, Sanon S, Hilou A. Antiplasmodial properties of plants isolated flavonoids and their derivatives. Int J Herb Med. 2018;6(5):43-56. wwwflorajournal.com.

22. Kamaraj C, Balasubramani G, Siva C, Raja M, Balasubramanian V,m Raja S, et al. Ag Nanoparticles Synthesized Using b-Caryophyllene Isolated from Murraya koenigii: Antimalarial (Plasmodium 
falciparum 3D7) and Anticancer Activity (A549 and HeLa Cell Lines) J. Clust. Sci. 2017; $28,1667$.

23. Jomaa H, Wiesner J, Sanderbrand S, Altincicek B, Weidemeyer C, Hintz M, Turbachova I, et al. Inhibitors of the nonmevalonate pathway of isoprenoid biosynthesis as antimalarial drugs. Science. 1999;285:1573-6.

24. Goldstein JL, Brown MS. Regulation of the mevalonate pathway. Nature. 1990;343:425-30.

25. Herbert RG, Emília AK, Valnice JP, Alicia SC, Fulgencio AAD, Alejandro MK. Terpenes Arrest Parasite Development and Inhibit Biosynthesis of Isoprenoids in Plasmodium falciparum. Antimicrob Agents Chemother. 2004;48:7 2502-9.

26. Wang KC, Ohnuma S. Isoprenyl diphosphate synthases. Biochim Biophys Acta. 2000;1529:33-48.

27. Ravikumar S, Inbaneson SJ, Suganthi P. In vitro antiplasmodial activity of ethanolic extracts of South Indian medicinal plants against Plasmodium falciparum. Asian Pac J Trop Biomed. 2012; 1-9 (Available at: .

28. Kirby GC, O'Neil MJ, Philipson JD, Warhurst DC. In vivo studies on the mode of action of quassinoids with activity against chloroquine resistant Plasmodium falciparum. Biochem Pharmacol. 1989;38:4367-74.

29. Dubar F, Egan TJ, Pradines B, Kuter D, Ncokazi KK, Forge D. The antimalarial ferroquine: role of the metal and intramolecular hydrogen bond in activity and resistance. ACS Chem Biol. 2011;6(3):27587.

30. Wright CW. Antiprotozoal Natural Products. In: Evans EC, editor, Trease and Evans Pharmacognosy. 2009; 16th ed. pp. 428-434, Edinburgh, Saunders.

31. Abdel-Hameed ES, Salih A, Bazaid SA, Shohayeb MM, El- Sayed MM, El-Wakil EA. Phytochemical studies and evaluation of antioxidant, anticancer and antimicrobial properties of Conocarpus erectus L. growing in Taif, Saudi Arabia. Eur J Med Plants. 2012;2:93-112.

32. Mahavorasirikul W, Viyanant V, Chaijaroenkul W, Itharat A, Na- Bangchang K. Cytotoxic activity of Thai medicinal plants against human cholangiocarcinoma, laryngeal and hepatocarcinoma cells in vitro. BMC Complement Altern Med. 2010;10:55.

33. Lorke D. A new approach to tropical acute toxicity testing 1983, Arch. Locksley HD, Murray IG. Extractives from Guttiferae. Part XIX. The Isolation of two benzophenones, six xanthones and two biflavonoids from the hearthwood of Allanblankia floribunda Oliver. J. Chem. Soc. 1971; 1332-1340.

34. Blunt JW, Boswell JL, Boyd M, Cardellina IIJH, Fulle RW, Guttiferone F. The first prenylated benzophenone from Allanblankia stuhlmannii. J of Nat Prod. 1999;62:130-2.

35. Nagem TJ, Peres V. Trioxygenated naturally occurring xanthones. Phytochemistry. 1997;44:199-214.

36. Nagem TJ, de Oliveira F, Peres V. Tetraoxygenated naturally occurring xanthones. Phytochemistry. 2000;55:683-710.

37. Debelle FD, Vanherwghem J, Nortier JL. Aristolochic acid nephropathy: A worldwide problem. Kidney Int. 2008;74:158-69. 


\section{Figures}

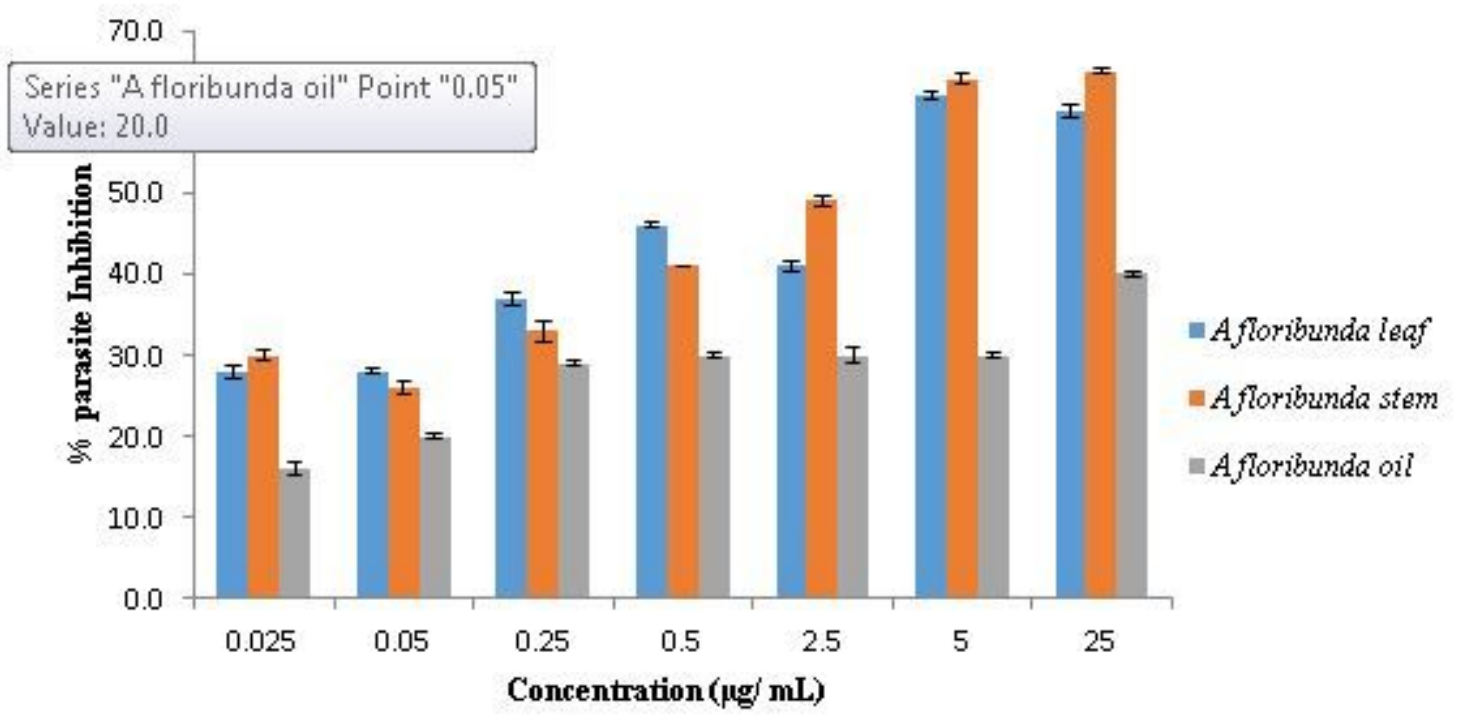

\section{Figure 1}

Percentage parasite growth inhibition at different concentrations of A. floribunda extract

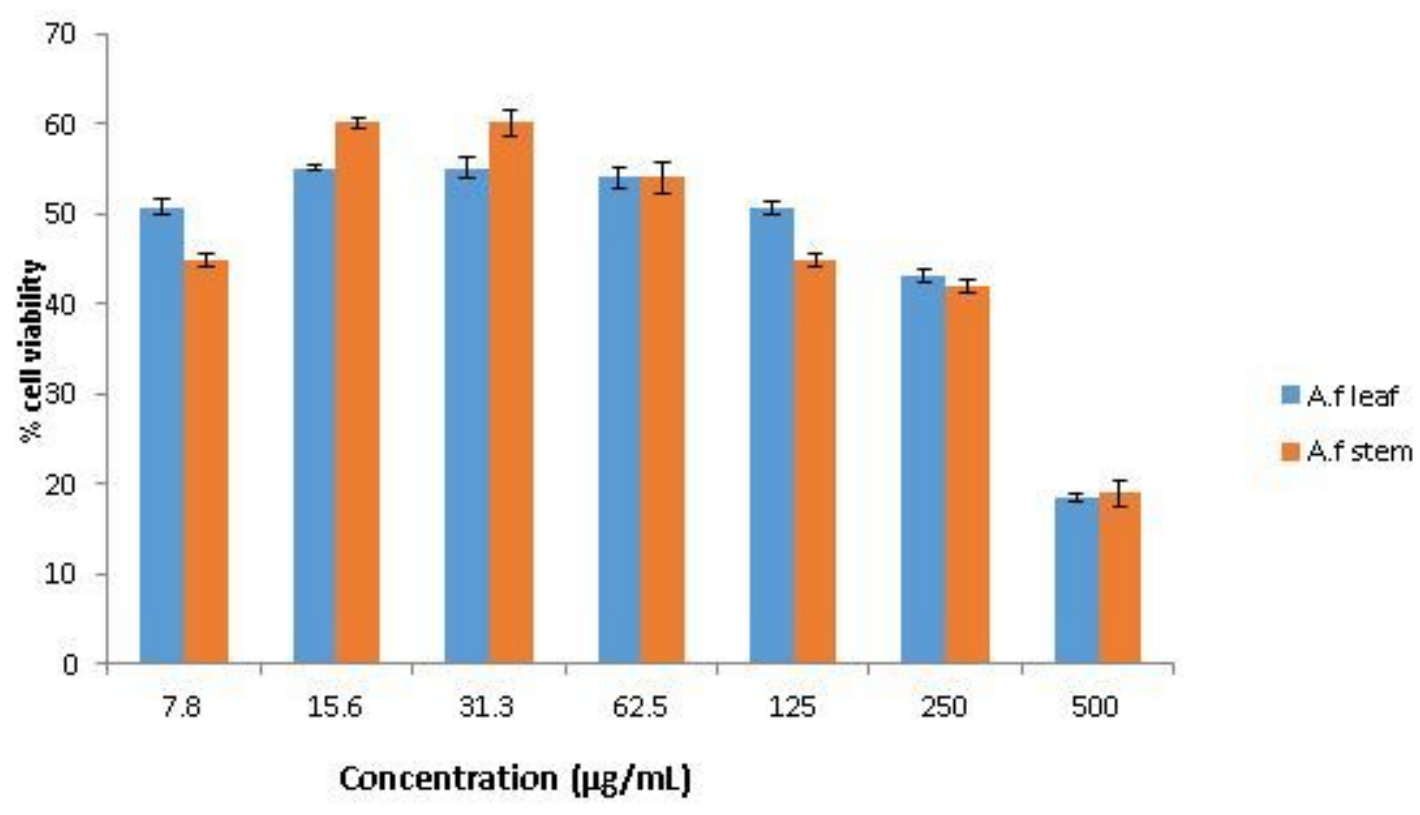

\section{Figure 2}

Percentage cell viability at various concentrations of A. floribunda leaf and stem bark extracts on Vero cell line 


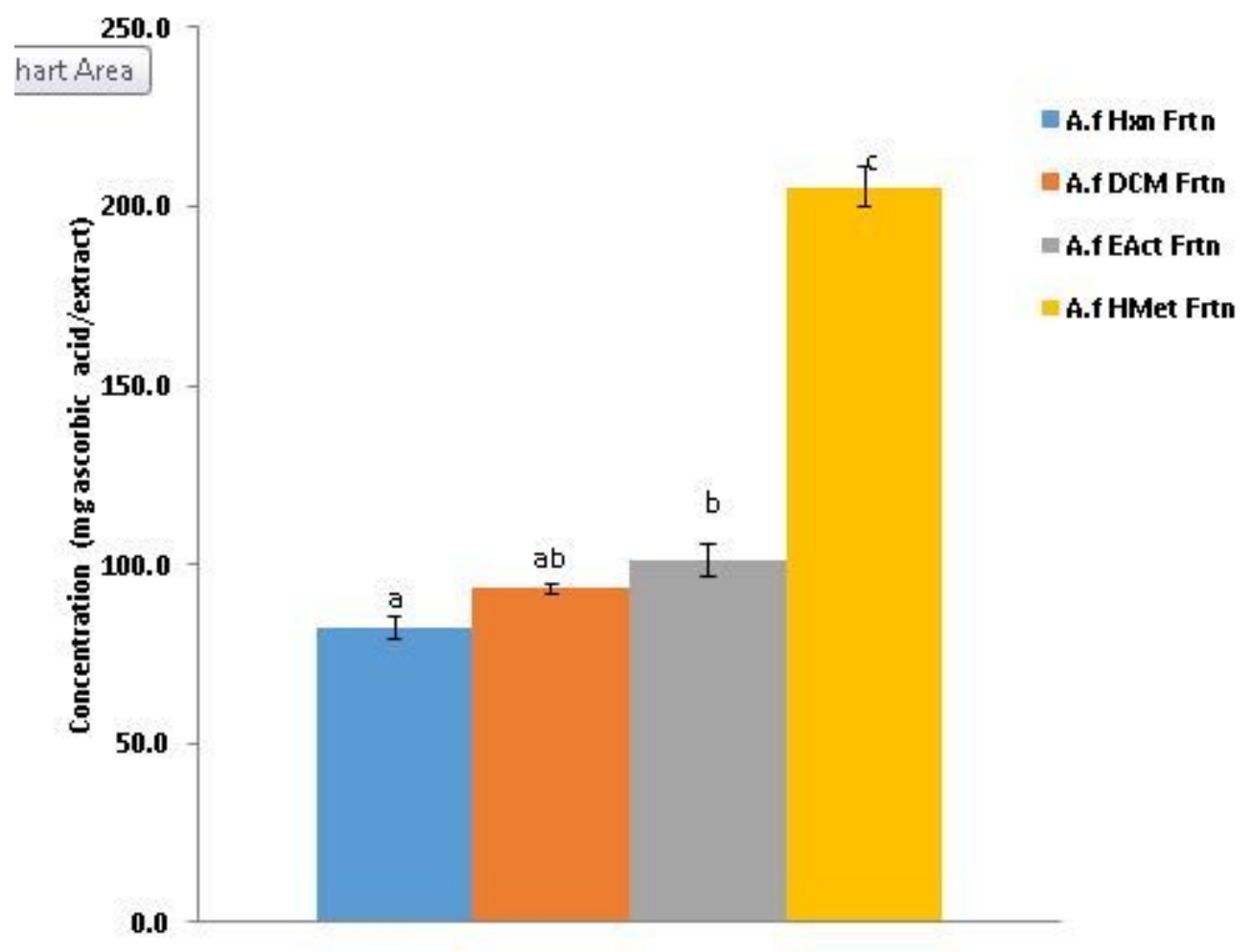

Figure 3

Total Antioxidant Capacity of A. floribunda Stem Bark Fractions Values are expressed as mean \pm SEM ( $\mathrm{n}$

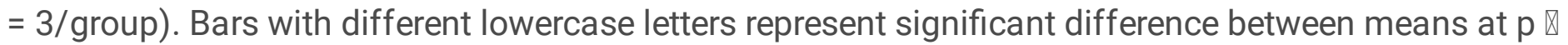
0.05. Where: A.f Hxn Frtn = A. floribunda stem bark hexane fraction; A.f DCM Frtn = A. floribunda stem bark dichloromethane fraction; A.f EAct Frtn = A. floribunda stem bark ethylacetate fraction; A.f HMet Frtn $=\mathrm{A}$. floribunda stem bark hydromethanol fraction.

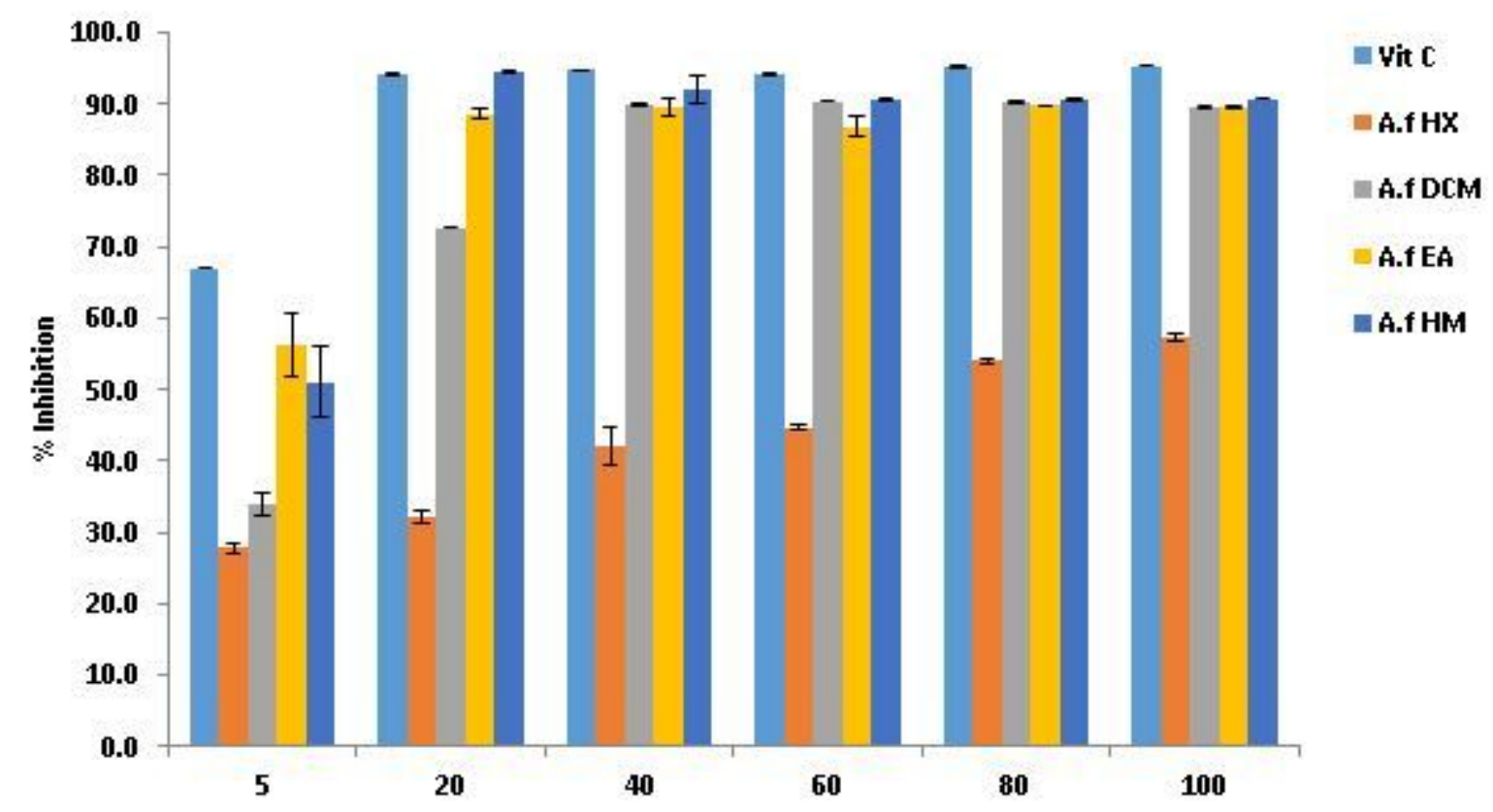


Figure 4

DPPH Radical Scavenging Ability of A. floribunda Stem Bark Fractions Values are expressed as mean \pm SEM ( $n=3$ /group). Where: A.f Hx = A. floribunda stem bark hexane fraction; A.f DCM = A. floribunda stem bark dichloromethane fraction; A.f EA = A. floribunda stem bark ethylacetate fraction; A.f HM = A. floribunda stem bark hydromethanol fraction.

120

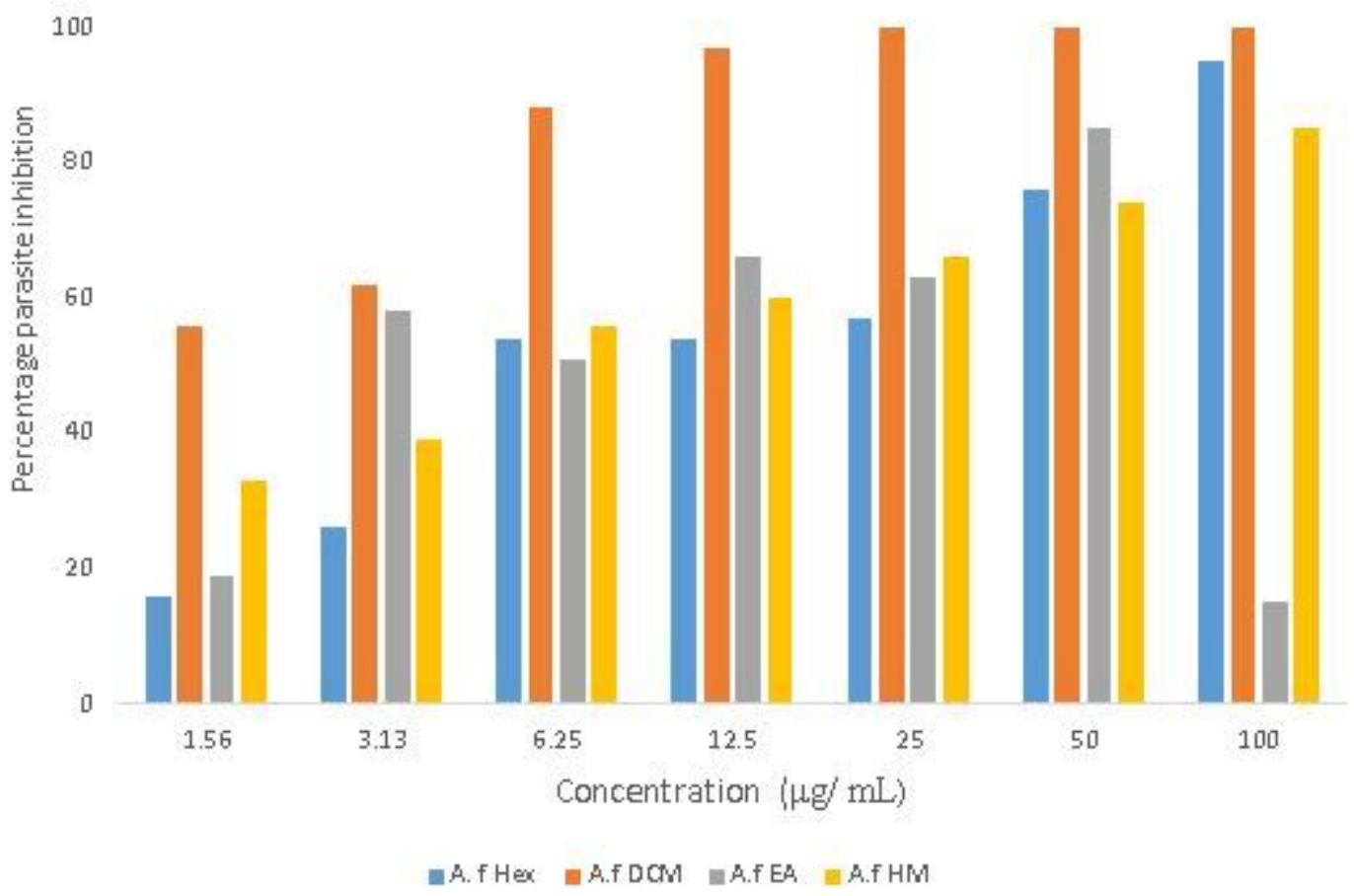

Figure 5

Percentage parasite growth inhibition at different concentrations of A. floribunda fractions. Values are expressed as mean \pm SEM ( $n=3$ /group). Where: A.f $H x=A$. floribunda stem bark hexane fraction; A.f $\mathrm{DCM}=\mathrm{A}$. floribunda stem bark dichloromethane fraction; A.f EA = A. floribunda stem bark ethylacetate fraction; A.f HM = A. floribunda stem bark hydromethanol fraction. 
Print of window 38: Current Chromatogram(s)

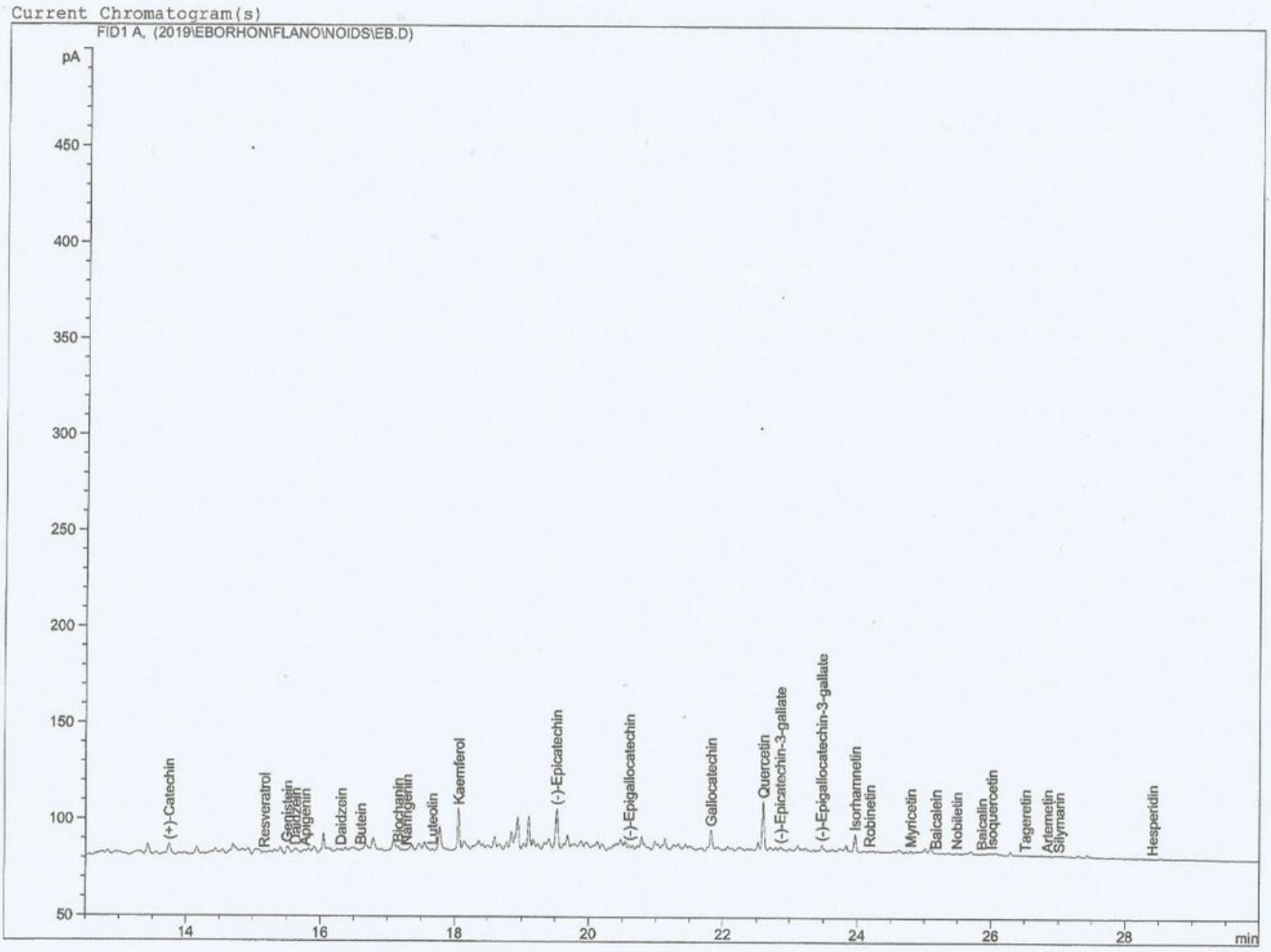

Instrument $16 / 10 / 2019$ 1:13:39 PM

Page 1 of 1

Figure 6

Chromatogram showing the names and amount of the various flavonoids present in dichloromethane fraction 
Print of window 38: Current Chromatogram(s)

Current Chromatogram(s)

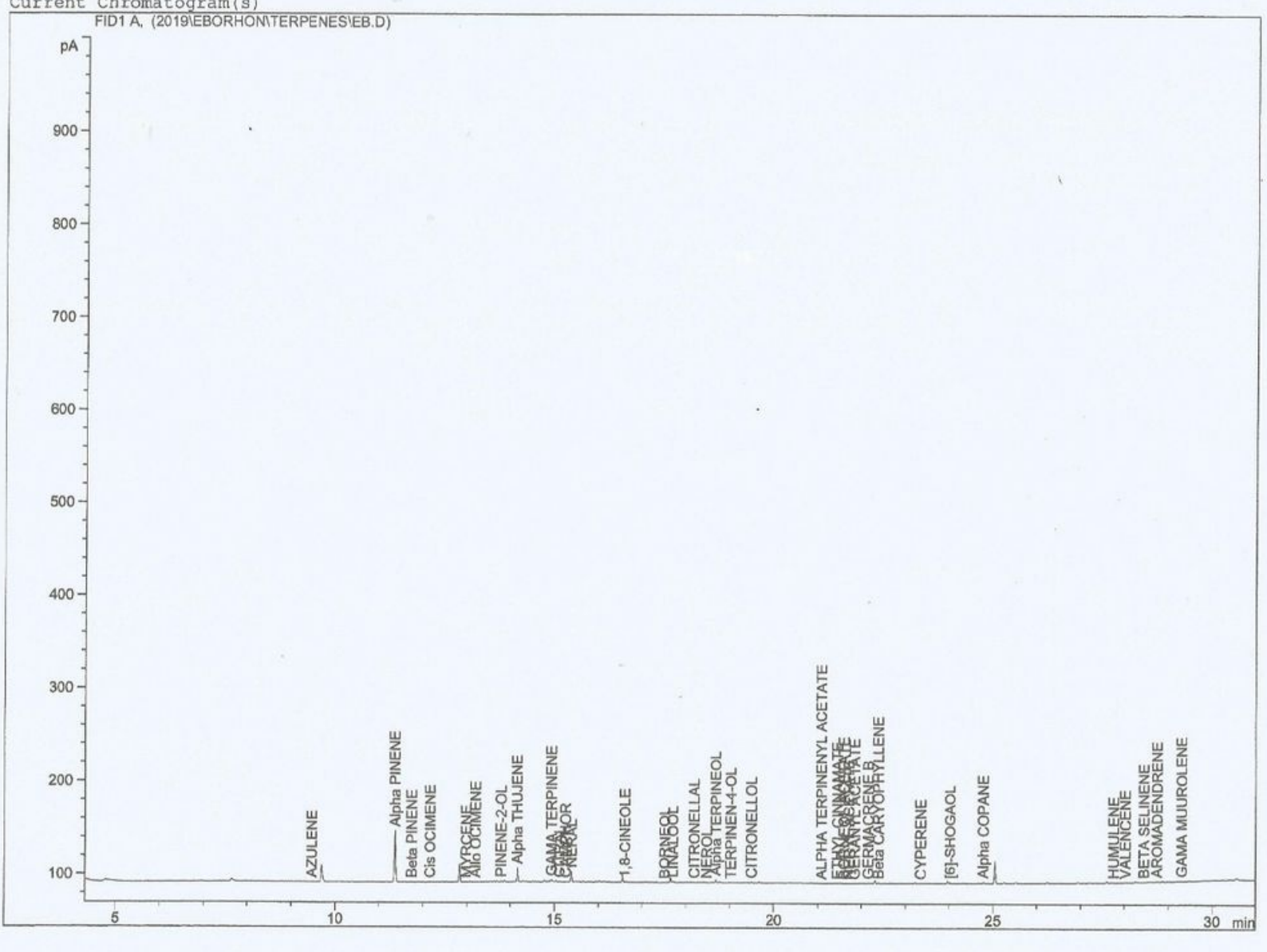

Figure 7

Chromatogram showing the names and amount of the various terpenes present in dichloromethane fraction 
Print of window 38: Current Chromatogram(s)

Current Chromatogram(s)

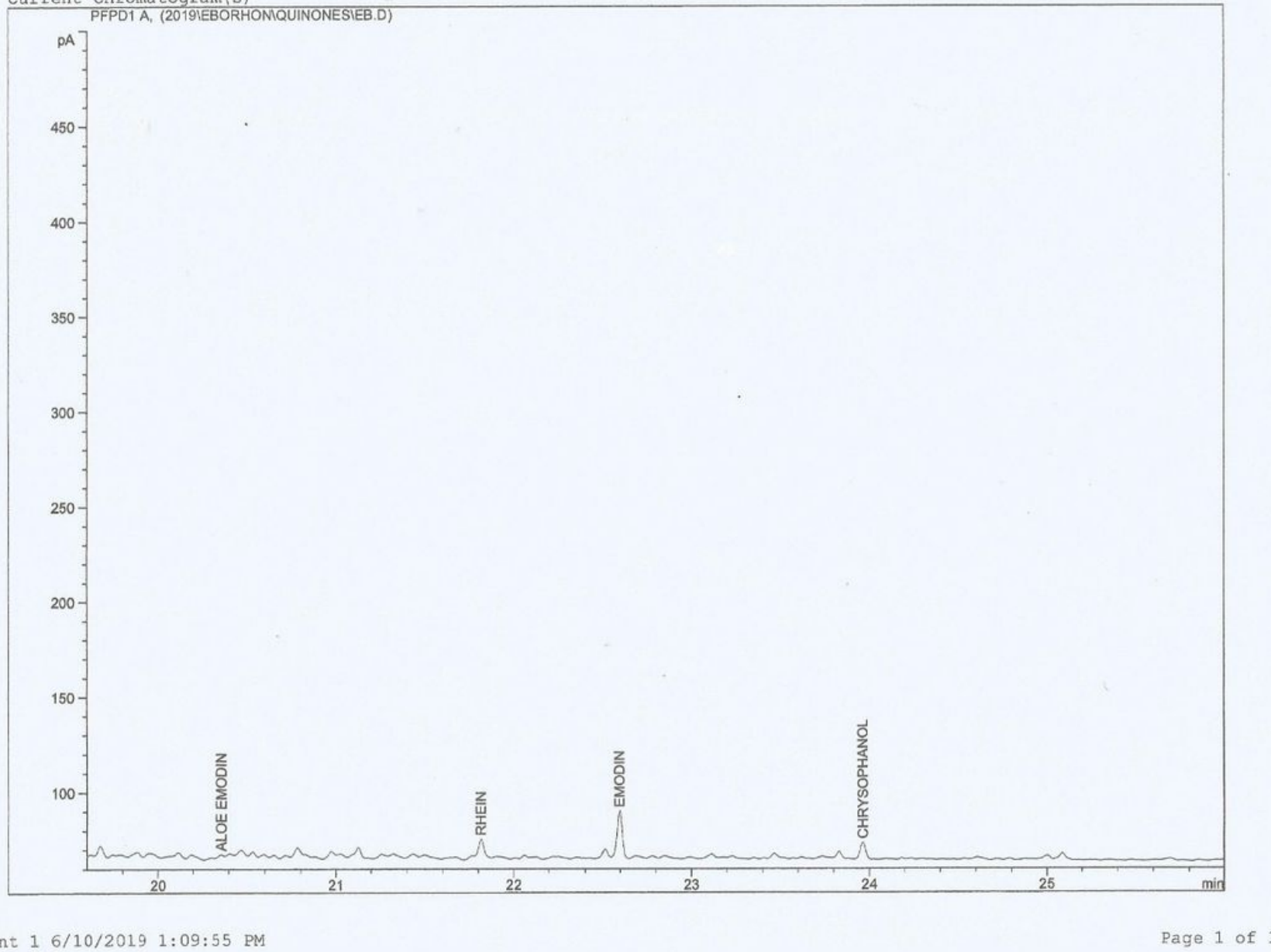

Figure 8

Chromatogram showing the names and amount of the various quinones present in dichloromethane fraction 
Print of window 38: Current Chromatogram(s)

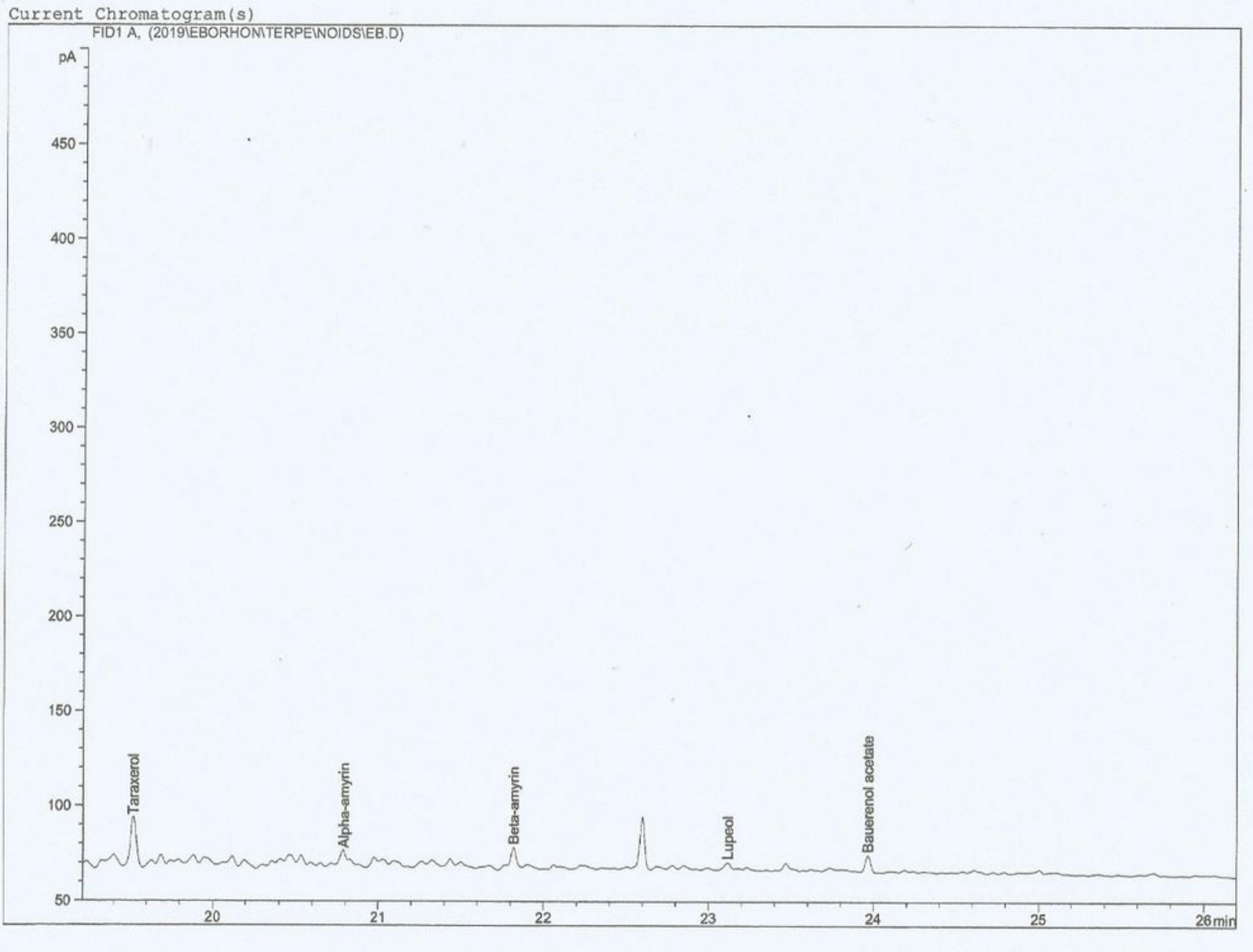

Figure 9

Chromatogram showing the names and amount of the various terpenoids present in dichloromethane fraction 
Print of window 38: Current Chromatogram(s)

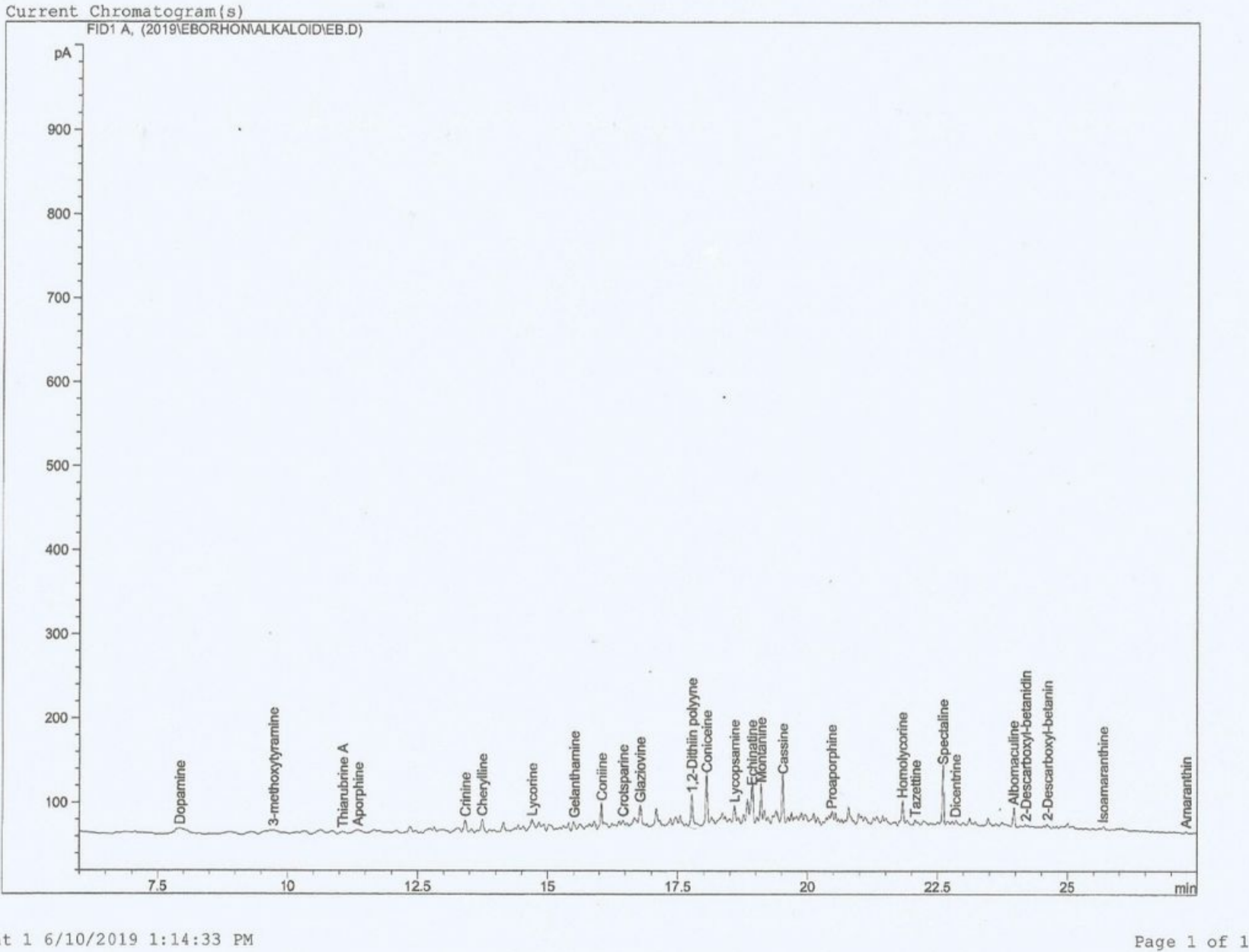

Figure 10

Chromatogram showing the names and amount of the various alkaloids present in dichloromethane fraction 
Print of window 38: Current Chromatogram(s)

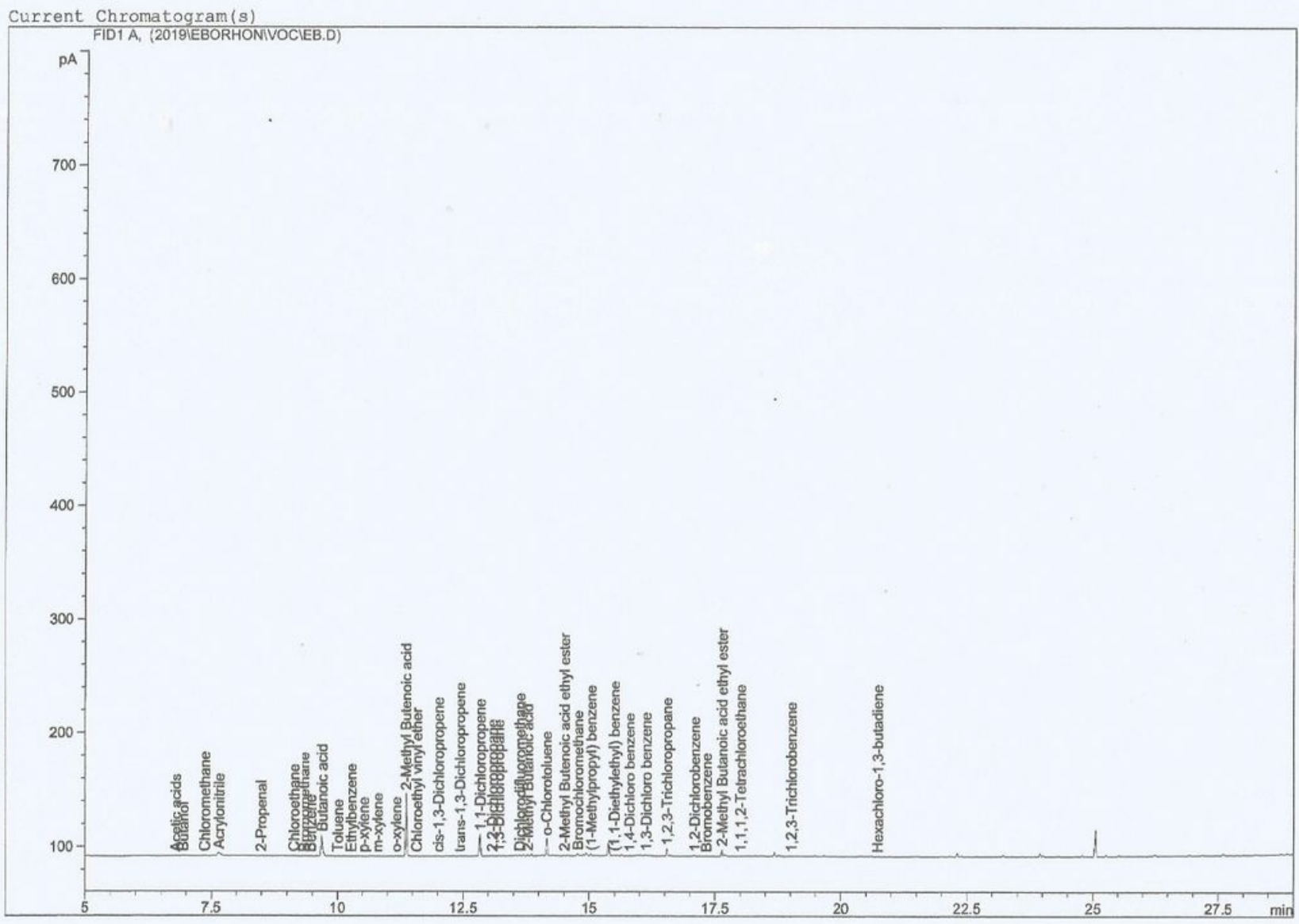

\section{Figure 11}

Chromatogram showing the names and amount of the variousvolatile organic constituents present in dichloromethane fraction

\section{Supplementary Files}

This is a list of supplementary files associated with this preprint. Click to download.

- supplement1.docx 